\title{
ESTADO E ORGANIZAÇÕES DA SOCIEDADE CIVIL NO BRASIL CONTEMPORÂNEO: CONSTRUINDO UMA SINERGIA POSITIVA?
}

\author{
Cláudia Feres Faria
}

\begin{abstract}
RESUMO
Este artigo busca analisar o padrão de relação mantido pelo governo Lula com os movimentos e as organizações da sociedade civil (OSCs) no péríodo de 2003 a 2006. O objetivo é investigar se e quais janelas de oportunidades foram criadas para o estabelecimento de uma "sinergia positiva" entre o Estado e a sociedade civil durante esse mesmo periodo. A hipótese da qual partimos é de que a criação de novos espaços participativos, embora seja condição importante para assegurar uma dinâmica inclusiva efetiva, não é suficiente. A análise empreendida mostra que apesar de o governo Lula ter construído as bases de um novo pacto com a sociedade civil organizada por meio da criação, ampliação e institucionalização de novos espaços participativos, tal prática não se transformou em uma política de governo majoritariamente sustentada. Desta forma, os esforços empreendidos até aqui para a construção e o aperfeiçoamento da participação das organizações da sociedade civil nas políticas públicas do governo Lula tornam-se marginais e seletivos, comprometendo, assim, as potencialidades inclusivas que estes mesmos esforços poderiam gerar.
\end{abstract}

PALAVRAS-CHAVE: Estado; organizações da sociedade civil; participação; governo Lula.

\section{INTRODUÇÃO}

Sabe-se que o aprofundamento da democracia requer um conjunto de formas participativas que ampliem as chances de vocalização e expressão de um número cada vez maior de pessoas, capacitando-as a partilharem autonomamente o exercício do poder político. Este reconhecimento vincula-se à crença de que a democracia precisa, para se consolidar, estar amparada em um conjunto de valores democráticos construídos e exercidos mediante as práticas cotidianas dos atores na sociedade. Nesse sentido, para além da constatação da importância da dinâmica institucional para o fortalecimento de uma determinada democracia, enfatiza-se também a importância da dinâmica societária por meio da prática de um conjunto de movimentos, organiza-

\footnotetext{
1 Gostaria de agradecer aos representantes das organizações da sociedade civil e do governo pela disponibilidade em concederem entrevistas e informações sobre os processos participativos em curso no governo de Luís Inácio Lula da Silva. Agradeço, simultaneamente, os comentários e as sugestões críticas dos dois pareceristas anônimos da $R e$ vista de Sociologia e Política. É importante ressaltar, entretanto, que a responsabilidade pelos resultados da análise e pela versão final deste artigo é inteiramente minha.
}

ções e associações que possibilitarão a formação de uma cultura política norteadora de ações capazes de revigorarem, a um só tempo, o sentido da democracia e sua arena político-institucional (Parlamento, estruturas burocrático-administrativas etc.).

Do ponto de vista teórico, esta mesma crença encontra-se presente nas obras de diferentes autores: de Alexis de Tocqueville (1977) a Robert Putnam (1996), de Jürgen Habermas (1996) a Cohen e Rogers (1995). Em todas elas, a participação cívica é considerada uma variável determinante para a ampliação e para o fortalecimento das democracias, tanto no que diz respeito ao plano sociocultural quanto no que diz respeito à dimensão político-institucional.

Em Tocqueville, esta participação concretizase por meio das associações secundárias de caráter voluntário que mediam a relação entre o Estado e os indivíduos. Segundo o autor de $A$ democracia na América (1977), as associações estimulam os indivíduos a saírem de suas relações primárias, educando-os para uma vida pública; induzem a formação de uma consciência cívica, deslocando o auto-interesse imediato em direção a um "interesse bem compreendido"; cultivam a 
reciprocidade e a confiança entre os indivíduos, capacitando-os a desenvolverem tarefas que eles não realizariam sozinhos. Por isso, a qualidade da democracia liberal constitucional estaria intrinsecamente vinculada à qualidade da sociedade na qual ela está inserida, especialmente ao cultivo das virtudes cívicas oriundas dos vínculos associativos nela estabelecida (TOCQUEVILLE, 1977; WARREM, 2001) $)^{2}$.

Seguindo os passos de Tocqueville, a literatura do pluralismo americano também atribui importância às associações intermediárias ao defenderem a existência de uma pluralidade de grupos de interesses, bem como a formação de uma cultura política robusta que irá influenciar o desempenho institucional das democracias modernas (ALMOND \& VERBA, 1963; DAHL, 2000). Putnam (1996) postula igualmente que, quando os cidadãos adquirem capacidades para agirem coletivamente, eles passam a monitorar, participar e pressionar os governos, tornando-os mais democráticos. A participação em associações civis pode apresentar, portanto, efeitos democráticos, dado que fortalece os mecanismos representativos e induz ao cultivo das habilidades organizacionais e das virtudes cívicas.

Em um outro espectro teórico que não aquele estritamente liberal, Jürgen Habermas (1984; 1996), mediante o conceito de esfera pública ${ }^{3}$, vem reforçar a importância da participação das associações voluntárias e dos movimentos sociais no fortalecimento da democracia. Esse

\footnotetext{
2 Os impactos democráticos do associativismo civil não são homogêneos. Muitas das práticas associativas podem redundar em problemas e não em soluções para o fortalecimento de uma democracia, tornando necessário, portanto, avaliá-las mediante suas ações cotidianas. Para uma excelente discussão a respeito, ver Warren (2001) e Armony (2004).

3 Habermas, em Mudança estrutural da esfera pública (1984), analisa o surgimento, no século XVII, de uma esfera pública esclarecida e politizada e seu gradual desenvolvimento no capitalismo. Se, na sociedade feudal, o público representava passivamente uma ordem política pré-ordenada, com o surgimento do capitalismo, um espaço público, formado por cidadãos privados, vai se consolidando. Esses sujeitos passam a ter a possibilidade de julgar coletivamente a autoridade do Estado, cuja legitimidade torna-se dependente desta opinião discursivamente formada. Habermas ressalta a importância deste espaço na promoção da autodeterminação democrática e da responsabilidade pública.
}

autor acredita que a tematização e a apresentação em público de novas questões tem um duplo efeito: renovam os potenciais críticos oriundos do mundo da vida e ampliam os limites do sistema político e de sua pauta de discussão mediante fluxos comunicativos que atingirão os centros decisórios, influenciarão os tomadores de decisões e conferirão legitimidade às decisões tomadas.

A esfera pública habermasiana constitui, assim, um espaço em que ocorrerão primeiramente a constituição de uma opinião e de uma vontade democrática. Sua base social é formada por uma sociedade civil composta por associações, organizações e movimentos sintonizados com a ressonância dos problemas societários nas esferas da vida privada, que deverão ser transmitidos para a esfera pública. Estas organizações da sociedade civil influenciarão a definição dos problemas que serão tematizados por meio da esfera pública. Uma vez publicizados, tais problemas poderão ser tratados pelo sistema político-administrativo (HABERMAS, 1996, p. 363). A esfera pública estabelece, portanto, uma mediação entre, de um lado, a sociedade civil e, do outro, o sistema político-administrativo ${ }^{4}$.

Autores como Cohen e Rogers (1995), Bohman (1996) e Fung (2003), em diálogo com as elaborações habermasianas, buscam analisar formatos participativos que poderão promover tanto o debate público - indutor da formação de consensos e/ou cooperação pública - quanto decisões efetivas, pois que asseguradas institucionalmente a partir de fóruns deliberativos ${ }^{5}$.

O padrão democrático de uma sociedade passa aqui a ser avaliado não só pela densidade cívica de sua sociedade civil ou pela força de sua esfera

\footnotetext{
4 Esse modelo de esfera pública oferecido por Habermas diferencia-se do modelo bipolar da relação Estado e sociedade civil oferecido pelo "paradigma" tocquevilliano. Esta diferença tem, por sua vez, implicações teóricas e empíricas importantes para o sentido - ou os sentidos - da participação. Ver Costa (1997) e Warren (2001).

5 Ciente dos problemas oriundos do processo de complexificação das sociedades modernas, Habermas assegura tanto à esfera pública quanto às organizações da sociedade civil um papel limitado. Temendo a força dos códigos sistêmicos (dinheiro e poder) sobre as organizações dos atores da sociedade civil, bem como o processo de burocratização dessas organizações, Habermas reserva-lhes
} 
pública, mas também pela pluralidade de formas participativas institucionalizadas capazes de inserir novos atores no processo decisório destas mesmas sociedades. Acredita-se, com isso, que os atores societários deverão não só tematizar situações problemáticas e buscar influenciar os centros decisórios, mas também assumir funções mais ofensivas por meio de fóruns de deliberação pública.

Esta mesma abordagem inspirou Amartya Sen a chamar a atenção para a centralidade das instituições deliberativas para qualquer conceituação de desenvolvimento, uma vez que elas possibilitam o exercício autêntico da escolha social.

O retorno à democracia no Brasil foi marcado por estas mesmas crenças que vinculam o fortalecimento da democracia à consolidação das instâncias tradicionais de participação (o voto, as eleições e os partidos) como também à ampliação de novos canais participativos através dos quais os cidadãos brasileiros podem fortalecer seus laços societários e intervir na formulação e no controle das decisões coletivas. Os movimentos sociais e seus aliados institucionais buscaram traduzir tal crença em realidade institucional. A Constituição Federal de 1988 retrata como esta prática social ganhou forma no cenário político brasileiro. A partir dela, uma nova legislação participativa foi implementada, viabilizando a abertura de novos canais institucionais de participação. Exemplos paradigmáticos são encontrados nos dispositivos constitucionais que asseguram a realização de referendos, plebiscitos, iniciativas populares de leis, audiências públicas, orçamentos participativos, conselhos de políticas e outros.

Neste cenário, o Partido dos Trabalhadores (doravante PT) teve um papel ímpar como articulador institucional das demandas societárias

as funções de preservar e ampliar a infra-estrutura do mundo da vida e dar visibilidade aos problemas societários sem, contudo, resolvê-los. Esse caráter defensivo e pouco deliberativo imputado aos atores da sociedade civil torna a elaboração habermasiana acerca da importância das associações secundárias, organizações e movimentos sociais para a promoção e o fortalecimento da democracia passível de críticas. Habermas é acusado de negligenciar as possibilidades de ampliação dos mecanismos institucionalizados de formação da vontade política que conferiria poderes efetivos aos públicos deliberativos. Para uma análise crítica destas proposições, ver Faria (2000) e Avritzer e Costa (2004). pela ampliação destes novos espaços. Este mesmo partido, quando no governo de prefeituras e estados, inovou ao introduzir uma forma participativa de gestão pública reconhecidamente bem-sucedida: os orçamentos participativos. Ademais, muitas das primeiras experiências conselhistas tiveram os membros do PT como um dos seus principais articuladores (GOHN, 1995). O governo de Luís Inácio Lula da Silva (doravante governo Lula) nasce, portanto, sob este signo, ou seja, o de apoiar e ampliar esta rede participativa que, nos seus primórdios, foi, simultaneamente, fundada e fundadora deste mesmo partido.

Com o objetivo de aferir se e como esta promessa está sendo cumprida, procuraremos, neste artigo, analisar de que forma o governo Lula, na sua primeira gestão à frente da Presidência da República (2003-2006), relacionou-se com os movimentos e as organizações da sociedade civil (OSCs). Avaliaremos quais janelas de oportunidades foram criadas para o estabelecimento de uma "sinergia positiva" 6 entre o Estado e a sociedade civil durante este mesmo período.

6 A idéia de sinergia pressupõe, segundo Evans (1996; 2003), ações complementares entre Estado e sociedade civil. Uma sociedade civil dinâmica pode fortalecer as instituições do Estado ao passo que estas podem construir ambientes favoráveis para a dinamização desta própria sociedade. As ações das agências públicas podem, por exemplo, forjar redes de engajamento cívico entre os cidadãos que, por sua vez, serão utilizadas com fins desenvolvimentistas. Cidadãos engajados tornar-se-ão uma fonte de disciplina e informação para as agências públicas, bem como um auxílio para a execução de projetos. Além da relação entre Estado e sociedade civil, esta idéia envolve também atores privados. Evans (1996, p. 1120-1122) propõe uma distinção analítica entre complementaridade e embeddedness, em que a primeira é definida como uma forma convencional de conceituar relações de apóio mútuo entre atores públicos e privados, enquanto a segunda diz respeito às redes de relações entre representantes públicos e da sociedade civil que vão além dos limites entre público e privado. Assim, casos mais concretos de sinergia envolvem combinações variadas de complementaridade e embeddedness. Elaborações teóricas em torno desta idéia podem ser encontradas em diferentes trabalhos que buscam analisar o papel do Estado e da sociedade civil na promoção de "bons governos" no Brasil, como, por exemplo, Abers (1998) e Tendler (1998). Estamos utilizando aqui a idéia de sinergia para investigar em que medida o governo Lula (2003-2006), por meio de sua Secretaria Nacional de Articulação Social, foi capaz de potencializar uma relação virtuosa com os atores sociais inseridos na dinâmica participativa em curso no período analisado. 
Para tal, este artigo será estruturado da seguinte forma: na primeira seção realizaremos um breve panorama histórico sobre o fortalecimento da sociedade civil no Brasil dos anos 1990 e sua relação com o sistema político brasileiro, notadamente as estruturas administrativas do Estado brasileiro. Na segunda seção, buscaremos avaliar se e quais canais de participação foram abertos e/ou fortalecidos durante a primeira gestão de Lula, bem como a qualidade dos diálogos estabelecidos entre o governo e os atores sociais que fazem parte desta "infra-estrutura" participativa. Na terceira seção, conclusiva, teceremos algumas considerações acerca do potencial inclusivo gerado a partir da nova dinâmica construída entre Estado e OSCs neste mesmo período. Entendemos aqui por potencial inclusivo as possibilidades efetivas de transformação das discussões e diálogos empreendidos nestes espaços em decisões públicas que afetam diretamente a vida das pessoas envolvidas nestas organizações.

\section{SOCIEDADE CIVIL E SISTEMA POLÍTICO BRASILEIRO: DOS ANOS 1990 AO BRASIL DO SÉCULO XXI}

O espaço público brasileiro vem se tornando, desde a década de 1980, mais denso e complexo em função não só da sua diferenciação quantitativa, dado o surgimento de novos grupos, como, também, em função da sua diferenciação qualitativa, uma vez que se tornou mais organizado e mais autônomo (AVRITZER, 2002; GOHN, 2005; SANTOS, 2006).

Uma das consequências desta transformação pode ser sentida na mudança do próprio padrão de ação destes atores sociais: de uma postura de negação da institucionalidade vigente no final da década de 1970, passaram para uma postura mais dialogal, demandando e participando dos diversos canais participativos que se estruturavam. Neste movimento, além de mudar o perfil e o sentido da atuação destes novos atores, mudou também os limites do sistema político que se expandiu. Vários espaços participativos foram, então, construídos na interface entre governo e sociedade civil.

Tais espaços foram criados apesar da resistência explícita de quase todas as tentativas reformistas ocorridas no país que insistiam em dissociar a sociedade civil organizada da formulação e do controle dos "projetos modernizantes".
Por meio deles, os atores sociais e seus aliados políticos conseguiram provocar um tensionamento público em torno das diretrizes destes projetos. É sob esse registro que a década de 1990 iniciou-se.

Esta década assistiu à consolidação paulatina desses espaços participativos que, aliados à representação política e às formas corporativistas de negociação, assumiram papéis importantes no cenário nacional, ampliando as chances de vocalização de uma gama diversificada de atores. Assentadas na nova constitucionalidade inaugurada com a Carta de 1988, as novas formas institucionais de participação, nos diversos níveis da federação, começaram a ser recorrentemente utilizadas, estabelecendo dinâmicas diferentes entre Estado e sociedade civil. Nesse momento, assistimos a implantação de uma série de requisitos institucionais para dar prosseguimento ao processo de descentralização política e à formação de instâncias colegiadas cuja função é auxiliar na formulação, no controle e na execução das políticas setoriais. Os Planos Diretores Municipais passaram a contar com a participação dos cidadãos nas suas formulações. Alguns estados, como Minas Gerais e São Paulo, passaram a implementar as Audiências Públicas Legislativas, que abriram espaços para o debate entre os cidadãos e seus representantes nos Legislativos estaduais. Consolidaram-se as formas híbridas de participação ${ }^{7}$, como os Conselhos Gestores de Políticas Públicas e de Direitos e os Orçamentos Participativos. As organizações não-governamentais (ONGs) multiplicaram-se e assumiram novas responsabilidades $^{8}$. Enfim, a questão da institucionalização da participação passou a ser um fato explorado tanto na prática, quanto analiticamente. Entretanto, o grau "real" de influência alcançado pelos atores societários junto ao sistema político por meio destas instâncias institucionais de participação permanece ainda uma questão em aberto.

\footnotetext{
7 No sentido de que eles envolvem, pelo menos em tese, um partilhamento de processos deliberativos entre atores estatais e atores sociais ou associações da sociedade civil (cf. AVRITZER \& PEREIRA, 2005).

8 Para uma discussão sobre a caracterização destes novos atores em termos de definição, funções e relações com outros atores sociais e políticos nos âmbitos nacional e internacional, ver Landim (1996), Teixeira (2002), Pinto (2006) e Koslinki e Reis (2009).
} 
O real potencial deliberativo dos novos formatos participativos, a qualidade da representação no interior dos mesmos, a capacidade e a autonomia de ação dos atores sociais que deles participam, os constrangimentos impostos pelas assimetrias organizacionais, informacionais e/ou econômicas entre os atores sociais e políticos mostram que, se o potencial participativo da década anterior traduziu-se em ganhos institucionais, isso não pressupõe, naturalmente, a construção de relações equitativas entre atores do Estado e da sociedade civil. Ademais, a introdução destes novos formatos ocorreu em meio a mudanças profundas na ordem política e econômica brasileira decorrente da implantação, nas últimas décadas, de novos projetos reformadores da ordem social.

As conseqüências da hegemonia quase total do discurso neoliberal que se consolidou no Brasil em meados dos anos 1990, bem como de sua prática para o dinamismo societário e para os diversos formatos participativos em surgimento inscrevem-se naquilo que Dagnino denominou de "confluência perversa". Confluência marcada, segundo a autora, pela convivência simultânea de dois projetos distintos: o projeto neoliberal implantado e desenvolvido pelos diversos governos desde a eleição do ex-Presidente Collor de Mello e o projeto participativo que surgiu com o fim dos governos autoritários e foi tomando forma durante o processo de democratização do país (DAGNINO, 2004, p. 138).

As conseqüências imediatas desta "confluência perversa" para a implantação e consolidação dos formatos participativos podem ser aferidas pela forma como se passou a avaliar o processo de inclusão política dos grupos organizados. Longe de facilitar tal processo, o modelo de desenvolvimento imposto dificultou ainda mais esta inserção na medida em que se passou a avaliar o dinamismo societário ora de forma instrumental, repassando aos atores da sociedade civil responsabilidades próprias ao Estado, ora como entrave às necessidades de reestruturar o país mediante os desafios colocados pela sua inserção em uma ordem globalizada 9 (DAGNINO, 2004; NOGUEIRA, 2004).

9 O modelo de desenvolvimento adotado, ainda no governo Collor, tinha como eixo central a abertura comercial ao exterior e as privatizações. Por meio do Plano Collor I iniciou-se uma forte intervenção na ordem econômica e social. Administrativamente, a reforma executada foi con-
Tal fato pode ser comprovado mediante as análises sobre as funções que os novos formatos participativos assumiram a partir dos anos 1990 . Ao analisarem a relação entre os atores societários que transitavam nestes espaços e os representantes do Estado no governo Fernando Henrique Cardoso, Tatagiba (2002) e Teixeira (2002) mostram como as promessas inclusivas e democratizantes contidas nas suas normas regimentais encontravam-se ainda em disputa - decorrente, muitas vezes, do papel e das funções que os seus interlocutores institucionais lhes imputavam na prática. Assim, por exemplo, Teixeira afirma, ao analisar a relação estabelecida entre certas ONGs e o Programa Comunidade Solidária ${ }^{10}$, que este Programa "transferia recorrentemente as responsabilidades públicas do Estado para as comunidades, famílias e indivíduos organizados pelas ONGs, bem como selecionava suas parcerias em articulações diretas do executivo federal com as organizações por ele selecionadas" (TEIXEIRA, 2002, p. 122123). Para tal, as funções destas organizações mudaram, e algumas delas passaram a desempenhar a função de prestadoras de serviços que, via de regra, eram da responsabilidade do Estado. Assumiam tais funções em nome da eficiência que apresentavam, mas sem participarem da elaboração dos mesmos. Tatagiba (2002) analisou a situação ainda frágil em que se encontravam os Conselhos Gestores de Políticas Públicas diante da recusa dos governos em compartilhar efetivamente a elaboração e a execução das políticas públicas para os quais foram criados e/ou ampliar a sua gestão.

siderada um verdadeiro desmanche do setor público federal, sem resolver, contudo, o problema financeiro do Estado e piorando a qualidade dos serviços públicos. Ao assumir o cargo de Ministro da Fazenda, Fernando Henrique Cardoso deu início a um novo processo de reestruturação do país. A "era FHC" (1993-2002) realizou mudanças de vulto, principalmente no que diz respeito à reconfiguração do papel do Estado. Diante deste novo cenário, o governo FHC estabeleceu com os setores organizados da sociedade uma postura pouco dialógica, assumindo uma prática que ia desde a marginalização e a desqualificação de certos setores sociais até a repressão dos mesmos. Este governo buscou restringir suas negociações às arenas institucionais por ele escolhidas, notadamente o Congresso Nacional. Ver Pereira (1995), Abrúcio e Costa (1998) e Nogueira (2004).

10 Ao Programa Comunidade Solidária e à Secretaria Executiva - coordenadora dos programas do governo de Fernando Henrique Cardoso na área social - couberam a execução de projetos voltados para situações de fome e miséria aguda, de emergência e calamidade pública. 
Tais exemplos chamam a atenção para as dificuldades de operacionalização dos formatos participativos inseridos em um contexto marcado por um projeto político que, embora enfatizando a importância da sociedade civil, fazia-o de forma problemática, posto que não visava a um compartilhamento real dos mecanismos decisórios e, conseqüentemente, a um alargamento da cidadania política, mas sim a uma transferência de responsabilidades, principalmente em áreas como as referentes à política social.

Vale ressaltar, entretanto, que, se por um lado, tal análise pode nos ajudar a entender parte desta dificuldade, por outro, esta explicação não esclarece, por exemplo, a ineficácia, pelo menos aparente, de certos mecanismos participativos implantados sob a gestão do outro projeto, o participativo. Exemplo paradigmático tem sido a operacionalização do Conselho de Desenvolvimento Econômico e Social (CDES), que foi implantado no primeiro ano do governo Lula como "um espaço de discussão dos grandes projetos do governo com a sociedade civil". Sua composição já aponta os problemas inclusivos que ele carrega. Como mostrou Pinto, "a representatividade deste Conselho é problemática em dois sentidos: (1) a sociedade civil não é representada por suas organizações, mas por pessoas de conhecida liderança e (2) a escolha destas pessoas é de responsabilidade do presidente, o que não ajuda em nada a alargar a participação da sociedade civil na representação deste Conselho" (PINTO, 2004, p. 103) $)^{11}$.

Aqui vale a pena ressaltar outras variáveis além daquela referente ao contexto político no qual estes formatos participativos inserem-se. Como bem aponta Nogueira, ao aceitarem participar nos termos colocados e ao ocuparem os espaços propostos, "os movimentos sociais [e os seus representantes] vol-

11 O CDES é um órgão de assessoramento imediato da Presidência da República, criado com o objetivo de cumprir o papel de articulador entre governo e sociedade, para a viabilização do processo de Concertação Nacional. Implantado em 13 de fevereiro de 2003, auxilia na formulação de políticas e diretrizes específicas, voltadas ao desenvolvimento econômico e social, produzindo indicações normativas, propostas políticas e acordos de procedimento. Ele é integrado por representantes do governo, das entidades empresariais e sindicais e por representantes das organizações da sociedade civil (BRASIL. PRESIDÊNCIA DA REPÚBLICA. CONSELHO DE DESENVOLVIMENTO ECONÔMICO E SOCIAL, 2007). taram-se mais para a [tentativa de] gestão da política do que para a oposição a ela" (NOGUEIRA, 2004, p. 58). Nesse sentido, fizeram uma escolha que, como todas, têm custos. Diante disto, a questão sobre o que deve guiar as escolhas dos grupos quando as oportunidades de acesso aos centros decisórios emergem, torna-se fundamental.

Dryzek sugere que os "grupos [societários] só obterão ganhos se seus interesses estiverem conectados diretamente aos imperativos do Estado (ordem interna, sobrevivência externa, extração de recursos, acumulação e necessidade de legitimação). Se houver uma coincidência entre tais imperativos e os interesses dos grupos, estes poderão alcançar ganhos reais no sentido de determinarem ou, pelo menos influenciarem, o conteúdo da política pública. Se isto não acontecer, a inclusão ocorrerá mediante cooptação e/ ou oferecimento de prêmios simbólicos. Nesse caso, a inclusão ocorrerá vis-à-vis uma restrição da relação democrática na esfera pública" (DRYZEK, 2000, p. 83).

Algumas análises nos ajudam a exemplificar tal proposição. Este é o caso do estudo empreendido por Paoli (2002) sobre as ações empresariais filantrópicas. Segundo a autora, a "filantropia empresarial" foi motivada pela percepção da agudização da pobreza e da desigualdade social no Brasil e, por isso, da necessidade de uma ação civil mais responsável e solidária por parte deste setor frente aos problemas sociais do país. Não obstante, o voluntariado empresarial, apesar de surgir em função da consciência da pobreza e da desigualdade social crescentes, não busca estabelecer qualquer debate público acerca de suas causas. Defende ações eficientes e privadas para minorar tal situação sem, entretanto, debater estratégias mais estruturantes e de longo prazo para extinguir suas causas. Dessa maneira, nos afirma Paoli, suas estratégias inserem-se "menos em uma lógica da cidadania e mais na eficiência da integração social para limitar o perigo e o risco inerente à presença aumentada dos excluídos e sem-direitos" (PAOLI, 2002, p. 414).

As análises sobre a expansão, nos anos 1990, de uma outra iniciativa participativa, os orçamentos participativos (doravante OPs), nos ajudam a precisar as variáveis envolvidas na implantação e no desenvolvimento dos novos formatos participativos que buscam realizar processos mais efetivos de inclusão política. 
Nesse caso, a avaliação positiva de alguns OPs reside na presença de um conjunto de elementos que, suspeitamos, não foram ainda completamente incorporados às outras formas participativas. A descentralização das decisões públicas, a introdução de fóruns públicos de discussão e deliberação, o incentivo institucional à participação dos atores organizacional e economicamente menos favorecidos e o comprometimento dos gestores públicos com o desenvolvimento virtuoso desta modalidade de gestão pública atestam o seu caráter mais inclusivo e democratizante (FARIA, 1996; ABERS, 1998; SOUZA SANTOS, 1998; NAVARRO, 1998; AVRITZER, 2002). Inseridos no mesmo contexto em que os outros experimentos aludidos, as experiências do OP mostraramse mais bem-sucedidas em função da presença destas variáveis.

É interessante observar que as críticas a este modelo de gestão pública municipal, ou pelo menos aos seus casos mais bem-sucedidos, emergem exatamente quando tais variáveis deixam de estar presentes. Navarro (2003), por exemplo, chama atenção para os problemas que a operacionalização do OP de Porto Alegre - a experiência mais virtuosa de OP citada pela literatura nacional e internacional - enfrentou nos últimos anos. Segundo o autor, depois de anos, o OP em Porto Alegre encontra-se dominado por uma elite partidária e suas bases organizadas na sociedade, o que o impede de se desenvolver e atingir novos grupos. Neste sentido, a burocratização de suas instâncias decisórias e a rotinização de suas regras, sem o devido cuidado com o monitoramente deste processo, vem transformando o OP de Porto Alegre em uma estrutura politicamente menos inclusiva. Conseqüentemente, a participação nesta forma de gestão pode tornarse, tal qual sugere Dryzek (2002), mais simbólica do que efetivamente inclusiva.

A disseminação de movimentos, associações e grupos organizados no Brasil, assim como das formas institucionais de participação construídas na interface entre sociedade civil e Estado no país apontam, claramente, para a complexificação da sociedade brasileira como um todo e de seu espaço público em particular. Atentar para essa complexidade significa perceber as múltiplas relações que se estabelecem no interior deste espaço, assim como da relação deste com o sistema político. Essa disseminação, se, por um lado, pressupõe um ganho em termos da dinamização da soci- edade brasileira e de um possível processo de aprendizado político institucional, por outro, nos remete a um conjunto de novas questões. Obviamente que estas surgem em um outro contexto, marcado não mais pela ausência deste espaço público, mas pela sua presença. A consciência desta presença nos obriga a refletir sobre o(s) tipo(s) de relação(ões) estabelecida(s) entre os atores organizados da sociedade civil e o atual governo. É com este espírito que, na próxima seção, descreveremos a "infra-estrutura" participativa criada durante o primeiro governo de Lula (III.1), bem como o método participativo criado por este governo para dialogar com os atores organizados da sociedade civil (III.2)

\section{O GOVERNO LULA(2003-2006) E A DINÂ- MICA PARTICIPATIVA}

\section{III.1. A "infra-estrutura" participativa}

Embora não existam dados precisos sobre o número de instituições participativas existentes no país, bem como das organizações e indivíduos nelas envolvidos ${ }^{12}$, podemos afirmar que novos espaços participativos foram criados e reformados durante o período entre 2003 e 2006. Dentre eles, ganham destaque os conselhos de Política ${ }^{13}$ e as conferências ${ }^{14}$ que atuam nos três níveis da

\footnotetext{
12 Em 1999, o Instituto Brasileiro de Geografia e Estatística (IBGE) divulgou a existência de 23987 conselhos municipais existentes no Brasil vinculados a diferentes políticas sociais como Saúde (5 426), Educação (5 011), Assistência Social (5 037), Direito da Criança e do Adolescente (3 949), Emprego e Trabalho (1 670), Meio Ambiente (1 117), Turismo (859), Habitação (440), Transporte (229) e Política Urbana (189). Destes, 18198 foram considerados deliberativos, 5634 consultivos e 155 de tipo ignorado (INSTITUTO BRASILEIRO DE GEOGRAFIA
} E ESTATÍSTICA, 1999).

13 Segundo Tatagiba (2002), “os conselhos de políticas são aqueles ligados às políticas públicas mais estruturadas ou concretizadas em sistemas nacionais. São, em geral, previstos em legislação nacional e são considerados parte integrante do sistema nacional, com atribuições legalmente estabelecidas no plano da formulação e implementação das políticas na respectiva esfera governamental. [...] São também concebidos como fóruns públicos de capacitação de demandas e negociação de interesses específicos dos diversos grupos sociais e como uma forma de ampliar a participação dos segmentos com menos acesso ao aparelho do estado" (idem, p. 49).

14 As Conferências podem ser definidas como espaços institucionais de deliberação das diretrizes gerais de uma determinada política pública. Elas envolvem um conjunto 
federação e nas diferentes políticas públicas, assim como as ouvidorias públicas, as mesas de negociação e os fóruns consultivos. $\mathrm{O}$ incetivo à criação e à reformulação destes espaços é indicativo da disposição do atual governo em dialogar com as OSCs.
No que diz respeito aos conselhos em âmbito nacional, Moroni (2006) constatou a existência de 64 conselhos, dentre os quais 11 foram criados no governo Lula e nove foram reestruturados neste mesmo período, como mostra o Quadro 1.

\section{QUADRO 1 - CONSELHOS NACIONAIS CRIADOS E REESTRUTURADOS DURANTE O GOVERNO LULA} (2003-2006)

\begin{tabular}{l} 
CONSELHOS NACIONAIS CRIADOS NO GOVERNO LULA \\
\hline 1) Conselho de Desenvolvimento Econômico e Social - CDES \\
2) Conselho Nacional de Segurança Alimentar - CONSEA \\
3) Conselho Nacional de Juventude - CNJ \\
4) Conselho das Cidades \\
5) Conselho de Transparência Pública e Combate à Corrupção \\
6) Conselho Nacional de Promoção da Igualdade Racial - CNPIR \\
7) Conselho Nacional de Desenvolvimento Industrial - CNDI \\
8) Conselho Nacional de Aqüicultura e Pesca - CONAPE \\
9) Conselho Nacional de Economia Solidária \\
10) Conselho Nacional do Programa Primeiro Emprego \\
11) Conselho Nacional do Esporte \\
\hline CONSELHOS NACIONAIS REFORMULADOS NO GOVERNO LULA \\
\hline 1) Conselho Nacional dos Direitos do Idoso \\
2) Conselho Nacional dos Direitos da Mulher - CNDM \\
3) Conselho Nacional de Combate à Pirataria e Delitos contra a Propriedade Intelectual \\
4) Conselho Nacional do Turismo \\
5) Conselho Nacional de Desenvolvimento Rural Sustentável - CONDRAF \\
6) Conselho Nacional de Recursos Hídrico \\
7) Conselho Nacional de Combate à Discriminação - CNCD \\
8) Conselho Assessor Nacional da Embrapa \\
9) Conselho Nacional dos Direitos da Pessoa Portadora de Deficiência - CONADE \\
\hline
\end{tabular}

FONTE: Moroni (2006) e Brasil. Secretaria-Geral da Presidência. Secretaria Nacional de Articulação Social (2007).

No que diz respeito às Conferências Nacionais, o Quadro 2 mostra que entre 2003 e 2006 foram realizadas 38 conferências nacionais e três internacionais convocadas, em sua maioria, pelo Governo federal.

QUADRO 2 - CONFERÊNCIAS NACIONAIS/INTERNACIONAIS REALIZADAS DURANTE O GOVERNO LULA (2003-2006)

\begin{tabular}{|c|c|c|}
\hline CONFERÊNCIA & PARTICIPANTES & ÓRGÃOS RESPONSÁVEIS \\
\hline 2003 & & \\
\hline IV Conferência Nacional de Assistência Social & $12000^{* *}$ & $\begin{array}{c}\text { Ministério de } \\
\text { Desenvolvimento Social e } \\
\text { Combate à Fome }\end{array}$ \\
\hline
\end{tabular}

de atores sociais para além daqueles que participam dos Conselhos de políticas. Elas são convocadas por decreto presidencial que delimita a temática e delega aos respectivos ministérios o dever de organizá-las. Ao regulamentá- las, o ministério em questão detalha os temas, objetivos e estabelece as comissões organizadoras, cronogramas e regulamentos para a implantação das reuniões regionais e eleições de delegados (MORONI, 2006; PINTO, 2006). 


\begin{tabular}{|c|c|c|}
\hline XII Conferência Nacional de Saúde & 104000 * & $\begin{array}{l}\text { Ministério da Saúde e } \\
\text { Conselho Nacional de } \\
\text { Saúde }\end{array}$ \\
\hline $\begin{array}{l}\text { I Conferência Nacional infanto juvenil do Meio } \\
\text { Ambiente }\end{array}$ & $\begin{array}{l}6000000^{*} \text { (em } 15148 \\
\text { escolas de todo país) }\end{array}$ & $\begin{array}{l}\text { Ministérios da Educação e } \\
\text { do Meio Ambiente }\end{array}$ \\
\hline I Conferência Nacional do Meio Ambiente & 65000 * & Ministério do Meio Ambiente \\
\hline $\begin{array}{c}\text { I Conferência Nacional de Aqüicultura e } \\
\text { Pesca }\end{array}$ & 16000 * & $\begin{array}{l}\text { Secretaria Especial de } \\
\text { Aqüicultura e Pesca }\end{array}$ \\
\hline $\begin{array}{l}\text { V Conferência Nacional dos Direitos da } \\
\text { Criança e do Adolescente }\end{array}$ & $7000 * *$ & $\begin{array}{l}\text { Secretaria Especial de } \\
\text { Direitos Humanos e } \\
\text { Conselho Nacional dos } \\
\text { Direitos da Criança e do } \\
\text { Adolescente }\end{array}$ \\
\hline I Conferência Nacional das Cidades & 300000 * & Ministério das Cidades \\
\hline $\begin{array}{c}\text { VIII Conferência Nacional de Direitos } \\
\text { Humanos }\end{array}$ & & $\begin{array}{c}\text { Câmara dos Deputados - } \\
\text { Comissão de Direitos } \\
\text { Humanos }\end{array}$ \\
\hline $\begin{array}{c}\text { I Conferência Nacional de Medicamentos e } \\
\text { Assistência Farmacêutica }\end{array}$ & $\begin{array}{l}1180 \text { delegados/as } \\
\text { nacionais }\end{array}$ & $\begin{array}{c}\text { Ministério da Saúde e } \\
\text { Conselho Nacional de } \\
\text { Saúde }\end{array}$ \\
\hline \multicolumn{3}{|l|}{2004} \\
\hline $\begin{array}{c}\text { I Conferência da Terra e da Água: reforma } \\
\text { agrária, democracia e desenvolvimento } \\
\text { sustentável }\end{array}$ & 8000 * & $\begin{array}{c}\text { Fórum Nacional pela } \\
\text { Reforma Agrária e Justiça } \\
\text { no Campo }\end{array}$ \\
\hline $\begin{array}{c}\text { I Conferência Brasileira sobre Arranjos } \\
\text { Produtivos Locais }\end{array}$ & Não informado & $\begin{array}{l}\text { Ministério do } \\
\text { Desenvolvimento, Indústria e } \\
\text { Comércio Exterior }\end{array}$ \\
\hline III Conferência Nacional de Saúde Bucal & 91000 * & $\begin{array}{l}\text { Ministério da Saúde e } \\
\text { Conselho Nacional de } \\
\text { Saúde }\end{array}$ \\
\hline $\begin{array}{l}\text { II Conferência Nacional de Ciência, } \\
\text { Tecnologia e Inovação em Saúde }\end{array}$ & 15000 * & $\begin{array}{c}\text { Ministérios da Saúde, da } \\
\text { Educação e da Ciência e } \\
\text { Tecnologia }\end{array}$ \\
\hline $\begin{array}{c}\text { I Conferência de Políticas Públicas para as } \\
\text { Mulheres }\end{array}$ & 121000 * & $\begin{array}{c}\text { Secretaria Especial de } \\
\text { Políticas para as Mulheres e } \\
\text { Conselho Nacional dos } \\
\text { Direitos da Mulher }\end{array}$ \\
\hline $\begin{array}{c}\text { IX Conferência Nacional dos Direitos } \\
\text { Humanos }\end{array}$ & $6580 *$ & $\begin{array}{l}\text { Secretaria Especial de } \\
\text { Direitos Humanos }\end{array}$ \\
\hline I Conferência Nacional do Esporte & 83000 * & Ministério de Esportes \\
\hline $\begin{array}{c}\text { II Conferência Nacional de Segurança } \\
\text { Alimentar }\end{array}$ & $11000 * *$ & $\begin{array}{l}\text { Conselho Nacional de } \\
\text { Segurança Alimentar }\end{array}$ \\
\hline I Conferência Nacional da Juventude & Não informado & $\begin{array}{l}\text { Câmara dos Deputados - } \\
\text { Comissão de Políticas } \\
\text { Públicas para a Juventude }\end{array}$ \\
\hline \multicolumn{3}{|l|}{2005} \\
\hline I Conferência Nacional de Cultura & 80000 * & $\begin{array}{l}\text { Ministério da Cultura e } \\
\text { Câmara dos Deputados }\end{array}$ \\
\hline $\begin{array}{l}\text { V Conferência Nacional dos Direitos da } \\
\text { Criança e do Adolescente }\end{array}$ & 10300 ** & $\begin{array}{l}\text { Conselho Nacional dos } \\
\text { Direitos Humanos e } \\
\text { Secretaria Especial de } \\
\text { Direitos Humanos }\end{array}$ \\
\hline II Conferência Nacional do Meio Ambiente & 88000 * & Ministério do Meio Ambiente \\
\hline
\end{tabular}




\begin{tabular}{|c|c|c|}
\hline V Conferência Nacional de Assistência Social & $400000 *$ & $\begin{array}{c}\text { Ministério de } \\
\text { Desenvolvimento Social e } \\
\text { Combate à Fome e } \\
\text { Conselho Nacional de } \\
\text { Assistência Social }\end{array}$ \\
\hline II Conferência Nacional das Cidades & 200000 * & $\begin{array}{c}\text { Ministério das Cidades e } \\
\text { Conselho Nacional das } \\
\text { Cidades }\end{array}$ \\
\hline $\begin{array}{c}\text { III Conferência Nacional de Saúde do } \\
\text { Trabalhador }\end{array}$ & 100000 * & $\begin{array}{l}\text { Ministérios da Saúde, do } \\
\text { Trabalho e Emprego e da } \\
\text { Previdência Social }\end{array}$ \\
\hline $\begin{array}{l}\text { III Conferência Nacional de Ciência, } \\
\text { Tecnologia e Inovação em Saúde }\end{array}$ & $\begin{array}{l}2000 \text { delegados/as } \\
\text { nacionais }\end{array}$ & $\begin{array}{c}\text { Ministério da Ciência e } \\
\text { Tecnologia }\end{array}$ \\
\hline $\begin{array}{c}\text { II Conferência Nacional sobre Arranjos } \\
\text { Produtivos Locais }\end{array}$ & Não informado & $\begin{array}{l}\text { Ministério do } \\
\text { Desenvolvimento, Indústria e } \\
\text { Comércio Exterior }\end{array}$ \\
\hline $\begin{array}{l}\text { I Conferência Nacional de Promoção da } \\
\text { Igualdade Racial }\end{array}$ & 95000 * & $\begin{array}{c}\text { Secretaria Especial de } \\
\text { Promoção da Igualdade } \\
\text { Racial }\end{array}$ \\
\hline $\begin{array}{c}\text { II Conferência Nacional de Aqüicultura e } \\
\text { Pesca }\end{array}$ & 27000 & $\begin{array}{l}\text { Secretaria Especial e } \\
\text { Conselho Nacional de } \\
\text { Aqüicultura e Pesca }\end{array}$ \\
\hline $\begin{array}{l}\text { III Conferência Nacional de Gestão do } \\
\text { Trabalho e da Educação na Saúde }\end{array}$ & $\begin{array}{l}2200 \text { municípios } \\
\text { realizaram } \\
\text { conferências } \\
\text { municipais }\end{array}$ & $\begin{array}{l}\text { Ministério da Saúde e } \\
\text { Conselho Nacional de Saúde }\end{array}$ \\
\hline \multicolumn{3}{|l|}{2006} \\
\hline $\begin{array}{l}\text { II Conferência Internacional da Reforma } \\
\text { Agrária e Desenvolvimento Rural }\end{array}$ & $\begin{array}{l}\text { Não informado } \\
\text { Presença: } 96 \text { países }\end{array}$ & $\begin{array}{l}\text { Ministério do } \\
\text { Desenvolvimento Agrário }\end{array}$ \\
\hline $\begin{array}{l}\text { VIII Conferência Internacional das Partes da } \\
\text { Convenção sobre Biodiversidade Biológica } \\
\text { (COP-8) }\end{array}$ & $\begin{array}{l}6000 \text { representando } \\
180 \text { países }\end{array}$ & $\begin{array}{l}\text { Ministério do Meio Ambiente } \\
\text { e Fórum Brasileiro de ONGs }\end{array}$ \\
\hline $\begin{array}{c}\text { Conferencia Regional das Américas sobre o } \\
\text { Plano de Ação contra Racismo, Discriminação } \\
\text { Racial, Xenofobia e Intoleranças Correlatas } \\
\text { (Durban +5), }\end{array}$ & Não informado & $\begin{array}{l}\text { Governos do Brasil e do } \\
\text { Chile }\end{array}$ \\
\hline IV Conferência Nacional de Saúde Indígena & $\begin{array}{l}12700 \text { nas aldeias e } \\
4500 \text { nos distritos } \\
\text { sanitários indígenas }\end{array}$ & $\begin{array}{l}\text { Ministério da Saúde, } \\
\text { Conselho Nacional de } \\
\text { Saúde e Fundação Nacional } \\
\text { de Saúde }\end{array}$ \\
\hline I Conferência Nacional dos Povos Indígenas & Não informado & $\begin{array}{l}\text { Ministério da Justiça e } \\
\text { Fundação Nacional do Índio }\end{array}$ \\
\hline $\begin{array}{c}\text { Il Conferência Nacional Infanto-Juvenil pelo } \\
\text { Meio Ambiente }\end{array}$ & Não informado & $\begin{array}{l}\text { Ministério do Meio Ambiente } \\
\text { e Ministério do Esporte }\end{array}$ \\
\hline $\begin{array}{l}\text { I Conferência Nacional dos Diretos da Pessoa } \\
\text { com Deficiência }\end{array}$ & Não informado & $\begin{array}{c}\text { Secretaria Especial de } \\
\text { Direitos Humanos e } \\
\text { Conselho Nacional de } \\
\text { Direitos da Pessoa } \\
\text { Portadora de Deficiência }\end{array}$ \\
\hline X Conferência Nacional de Direitos Humanos & Não informado & Câmara dos Deputados \\
\hline II Conferência Nacional do Esporte & Não informado & Ministério do Esporte \\
\hline $\begin{array}{c}\text { I Conferência Nacional dos Direitos da Pessoa } \\
\text { Idosa }\end{array}$ & Não informado & $\begin{array}{l}\text { Secretaria Especial de } \\
\text { Direitos Humanos }\end{array}$ \\
\hline I Conferência Nacional de Economia Solidária & Não informado & $\begin{array}{l}\text { Ministérios do Trabalho e } \\
\text { Emprego, do } \\
\text { Desenvolvimento Agrário e } \\
\text { do Desenvolvimento Social e } \\
\text { Combate à Fome }\end{array}$ \\
\hline
\end{tabular}




\begin{tabular}{|c|c|c|}
\hline $\begin{array}{l}\text { I Conferência Nacional de Educação } \\
\text { Profissional e Tecnológica }\end{array}$ & Não informado & $\begin{array}{l}\text { Ministério da Educação e } \\
\text { Fórum Nacional de Gestores } \\
\text { Estaduais de Educação } \\
\text { Profissional }\end{array}$ \\
\hline
\end{tabular}

FONTE: Moroni (2006) e Brasil. Secretaria-Geral da Presidência. Secretaria Nacional de Articulação Social (2007).

NOTAS: * soma dos participantes das etapas municipais, estaduais e nacional; ** soma dos participantes das etapas estaduais e nacional.

Como já mencionada na primeira seção deste trabalho, a abertura de novos canais de participação, embora relevante, nos diz pouco sobre a qualidade da prática democrática no interior dos mesmos. Para avaliá-la, um conjunto de variáveis devem ser mobilizadas, como, por exemplo, o tipo de política pública envolvida, o comprometimento do gestor com a participação, o tempo e a capacidade de moblização dos atores da sociedade civil envolvidos em cada política, o desenho institucional assumido, as regras que balizam o funcionamento das instituições participativas, entre outras (AVRITZER, 2002; TATAGIBA, 2004; FARIA, 2007).

Se elegermos as regras institucionais que criaram e/ou reestruturaram estes espaços participativos poderemos aferir, por exemplo, como eles são organizados, quais segmentos os compõem, a quem eles representam, quando e como organizam o processo deliberativo etc. Desta forma, mesmo sem podermos analisar a prática social no interior destes espaços a partir destes dados, uma vez que as regras e os desenhos instituicionais assumidos estruturam tais práticas sociais, esta análise nos permite antever a qualidade das mesmas (TATAGIBA, 2004; FARIA, 2007). Vejamos, por exemplo, o impacto das regras sobre a representação dos diversos segmentos no interior dos conselhos.

Para analisar a prática representativa nos conselhos compostos por representantes do governo e da sociedade civil é importante avaliarmos se e como esta representação é organizada. Descobriremos que quando ela ocorre a partir das instâncias municipais e estaduais, a legitimidade desta representação tende a ser maior, posto que ela se forma a partir de escolhas realizadas no próprio universo societário e não por meio de escolhas prévias feitas pelo poder executivo. Embora não seja possível realizar tal análise para todos os Conselhos, alguns casos revelam-se paradigmáticos, como os conselhos nacionais de Saúde, de Assistência Social e da Cidades (AVRITZER, 2007).

Um outro aspecto relevante diz respeito às re- gras referentes ao processo de escolha do Presidente do Conselho. Se partirmos do pressuposto que o ato eleitoral expressa, simultaneamente, o consentimento do representado para com o representante e a chance de controle do mesmo (MANIN, 1997), a indicação do presidente pelo governo fere não só o princípio representativo, como indica o monopólio do cargo pelo representante do governo, configurando de antemão a preponderância deste frente aos demais segmentos que compõem estes espaços. Esta prática incide negativamente sobre a autonomia dos representantes da sociedade civil, uma vez que, embora existindo paridade numérica entre os segmentos envolvidos, no que diz respeito ao processo decisório, o equilíbrio entre as partes é comprometido pelo maior poder de agenda e de controle do presidente. No que diz respeito aos conselhos nacionais, podemos afirmar que ainda são raros os casos onde o presidente é eleito diretamente pelos segmentos que deles fazem parte, embora o caso do Conselho Nacional da Saúde constitua-se uma exceção, dado que elegeu, pela primeira vez, um representante dos trabalhadores dos seviços de saúde.

É igualmente importante avaliar qual o envolvimento do gestor com estes espaços participativos. Este envolvimento importa porque confere maior poder às instituições participativas ao aproximar governo e sociedade e criar chances reais de diálogo entre as partes. Sabe-se que a ausência de representantes governamentais nestes espaços inviabiliza não só as possibilidade deste diálogo, como também as chances de encaminhamento institucional das decisões tomadas no interior destas instituições. Neste caso, o governo Lula diferencia-se do governo anterior na medida em que tem estado muito mais presente nestas instituições. Avritzer (2007) mostra, para o caso do Conselho Nacional de Saúde, que o Ministro da Saúde do atual governo esteve presente em 91\% das reuniões realizadas, ao passo que no governo de FHC, o Ministro participou somente de 14\% das reuniões. Se a idéia de sinergia aludida pressupõe o envolvimento de ambas instâncias, go- 
vernamental e societária, na construção de uma relação cooperativa que possa redundar em maior desenvolvimento, a ausência da disposição em participar compromete tal possibilidade.

No que diz respeito às Conferências Nacionais, chama a atenção o número de atores envolvidos: mais de dois milhões de pessoas participaram destes espaços promovidos nos diferentes níveis da federação. Este movimento todo em torno da concretização de espaços dialógicos entre governo e sociedade civil organizada aponta, mais uma vez, para a disposição do governo em ouvir os setores sociais organizados, principalmente no que concerne às políticas sociais. Entretanto, para que esta interlocução ocorra de forma inclusiva é preciso analisar, tal qual sugerido para os conselhos nacionais, como a representação da sociedade civil constrói-se, quem tem poder de agenda, como as decisões são alcançacadas e qual o impacto delas nas políticas públicas. Do contrário, o "ineditismo"15 da proposta, tão valorizado nos documentos oficiais, pode ser obscurecido pela ausência de impactos reais nas políticas vinculadas a estes espaços.

Nesse sentido, a criação de regras e/ou procedimentos claros para regularem o diálogo entre as OSCs e o governo federal é fundamental, principalmente em um contexto complexo como o nacional, que envolve não só uma escala muito maior - número de pessoas e territórios envolvidos como também uma burocracia mais ampla e heterogênea, além de uma multiplicidade de autoridades sobrepostas. A construção de parcerias efetivas, e não só simbólicas, entre Estado e sociedade civil demanda, assim, a construção de um método participativo ${ }^{16}$ que confira aos diálogos estabelecidos entre estes atores maior previsibi-

\footnotetext{
15 Esse ineditismo é atribuído não só ao número de participantes envolvidos, como também ao número de conferências que ocorreram pela primeira vez. Entre os anos de 2003 e 2006, foram realizadas, pela primeira vez, quinze conferências.

16 Denomina-se método participativo o conjunto de procedimentos elaborados para conduzir o processo de participação no nível nacional. Este conjunto nos diz pouco sobre a qualidade da participação no interior dos espaços participativos criados e/ou reformulados, mas, como já afirmado, pode nos permitir avaliar como estão sendo estruturadas as práticas sociais no interior dos mesmos. A análise da qualidade desta prática exigiria outro tipo de pes-
}

lidade, possibilitando formas mais permanentes de controle dos acordos efetivados. É exatamente esse método participativo que será objeto de análise na próxima sub-seção deste artigo.

\section{III.2. O governo Lula e o método participativo}

A confecção de um método participativo surge da intenção do governo Lula de criar um tipo diferente de governabilidade. Para além de sua relação com os outros entes da federação e com o Congresso Nacional, este governo busca relacionar-se com os movimentos organizados da sociedade civil por meio de uma secretaria própria: a Secretaria Nacional de Articulação Social, vinculada à Secretaria-Geral da Presidência (doravante SG-PR/ SNAS). Enquanto a Casa Civil é encarregada de estabelecer o diálogo entre os poderes instuídos, a Secretaria-Geral busca integrar as organizações da sociedade civil. Sua nova atribuição passou a ser "assistir o Presidente da República no desempenho de suas atribuições no que se refere ao relacionamento e articulação com as entidades da sociedade civil e à criação e implementação de instrumentos de consulta e participação popular de interesse do Poder Executivo" (BRASIL, 2003).

Constata-se que, diferente dos governos anteriores, a participação, aliada à representação, passou a fazer parte do repertório de ação do novo governo, ampliando, pelo menos formalmente, suas bases de sustentação e legitimidade. Os fóruns de discussão do Plano Plurianual (PPA) ${ }^{17}$ passaram a ser um dos espaços mais permanentes para a concretização destas novas bases. A elaboração do PPA 2004-2007 ocorreu mediante consultas aos representates da sociedade civil em fóruns

quisa empírica que não aquela aqui realizada. Esta se baseou em fontes documentais tais como jornais, panfletos, documentos oficiais, bem como em entrevistas e depoimentos de atores políticos e sociais considerados relevantes.

17 O PPA (Plano Plurianual) integra o ciclo orçamentário juntamente com a LDO (Lei de Diretrizes Orçamentárias) e a LOA (Lei Orçamentária Anual). Este ciclo é elaborado pelo poder Executivo federal e aprovado pelo Congresso Nacional. O PPA é elaborado a cada quatro anos e tem a função de definir as concepções, os programas, os objetivos e as metas do planejamento público para os próximos quatro anos. A LDO, bem como a LOA, são elaboradas anualmente e têm como funções, respectivamente, definir os programas prioritários, as metas físicas e as linhas gerais sobre a elaboração do orçamento do próximo ano e definir como e onde os recursos públicos serão aplicados. 
públicos realizados nos 26 estados da federação mais o Distrito Federal.

Para elaborar os procedimentos que balizaram a participação social, formou-se um grupo gestor composto pelo Ministério do Planejamento, Orçamento e Gestão, pela Casa Civil e pela SecretariaGeral da Presidência e as entidades de representação nacional dos trabalhadores, empresários e movimentos sociais. Tais procedimentos foram estabelecidos, ainda em 2003, com a Associação Brasileira de Organizações Não-Governamentais $(\mathrm{ABONG})^{18}$ e com um conjunto de redes e fóruns que constituem a Inter-Redes ${ }^{19}$.

A realização dos Fóruns contou, portanto, com a parceria deste conjunto de atores sociais cujo o objetivo era discutir as diretrizes para um novo modelo de desenvolvimento assentado não só nos princípios da justiça, mas também em estruturas que ampliassem a participação social e o controle público sobre o processo orçamentário e sobre os recursos públicos. Esperava-se, com isto, a formação de uma parceria concretizada mediante a participação dos setores organizados da sociedade civil na formulação, no acompanhamento e no monitoramento da implementação do PPA, nos processos de revisão anual e na elaboração de uma política de participação e de controle social do processo orçamentário federal (MORONI, 2006, p. 16).

O organograma abaixo (Figura 1) retrata como ocorreu o processo de elaboração do PPA 20042007:

FIGURA I - PROCESSO DE ELABORAÇÃO DO PLANO PLURIANUAL (2004-2007):

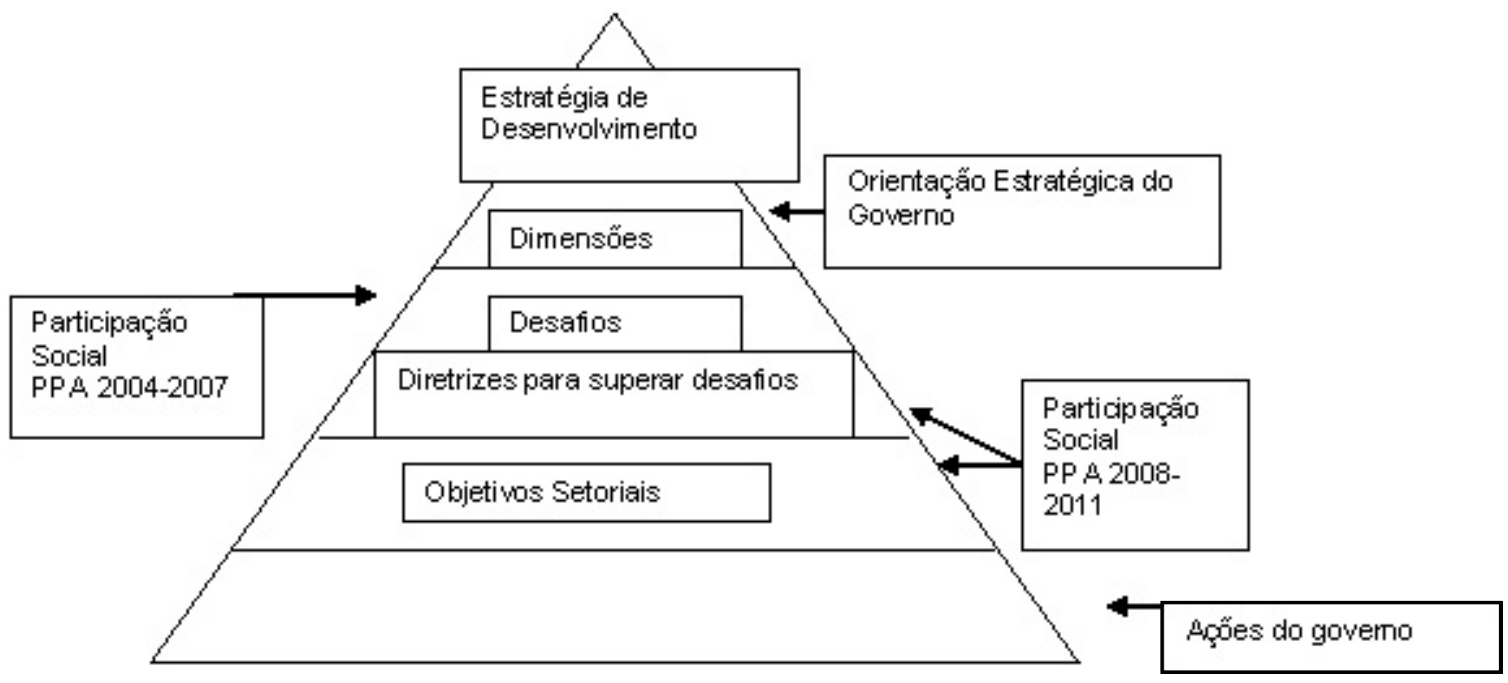

FONTE: Brasil. Secretaria-Geral da Presidência. Secretaria Nacional de Articulação Social (2007).

A “Orientação Estratégica do Governo", composta por 24 desafios organizados em três megaobjetivos, foi debatida em todos os estados da federação e no Distrito Federal por meio de consultas públicas que se concretizaram com a

18 A Associação Brasileira de Organizações Não-Governamentais (Abong) possui um universo de 271 ONGs filiadas, que atuam em áreas específicas de políticas setoriais como participação popular, educação, direitos humanos, gênero, trabalho e renda, saúde, meio ambiente, arte e cultura, comunicação, assistência social, questões urbanas e agricultura. (ASSOCIAÇÃO BRASILEIRA DE ORGANIZAÇÕES NÃO-GOVERNAMENTAIS, 2007). realização de Fóruns de Participação Social. Tais fóruns envolveram, segundo dados oficiais, 2170 entidades e 4700 atores sociais, além de governadores, prefeitos de capitais e parlamentares. Este debate resultou em 30 desafios, dos quais seis

\footnotetext{
19 A Inter-Redes: Direitos e Política define-se como "um espaço de articulação de redes e fóruns de organizações da sociedade civil brasileira que atuam, de diversas formas e com diversos temas, para o fortalecimento da esfera pública, a promoção de direitos e a proposição de políticas". São à ela filiadas aproximadamente 43 redes (INTER-REDES, 2007).
} 
foram novos e 21 tiveram sua redação alterada (BRASIL. SECRETARIA-GERAL DA PRESIDÊNCIA. SECRETARIA NACIONAL DE ARTICULAÇÃO SOCIAL, s/d.).

Após os debates em todo o país e o envio do Projeto de Lei do PPA ao Congresso Nacional, em 31 de agosto de 2003, diversas organizações sociais e redes acompanharam a tramitação do PPA no poder Legislativo.

Dois pontos contenciosos foram levantados pelos principais organizadores dos partícipes deste processo: o primeiro vinculado à organização do processo participativo e o segundo à implementação das propostas debatidas.

No que diz respeito ao primeiro ponto, criticou-se a "exiguidade do tempo" reservado para a preparação e realização das consultas. Este é um fator importante, recorrentemente apontado na literatura, para inibir iniciativas participativas. Argumenta-se, em geral, que iniciativas como estas exigem um tempo de organização muito grande que pode comprometer tanto a capacidade participativa dos atores sociais, quanto a capacidade do governo em tomar decisões (DAHL, 2000). Essas duas questões colocam problemas para os processos participativos uma vez que, por um lado, é necessário tempo para que os atores sociais dominem o processo e participem dele efetivamente, e por outro, a dinâmica decisória do governo, cujo o tempo muitas vezes não coincide com o calendário da dinâmica participativa, e que pode atropelar esta mesma dinâmica em curso.

O segundo ponto vincula-se à efetivação das questões debatidas e deliberadas nestes fóruns: segundo a percepção dos representantes destas organizações, "o rico processo participativo de consulta não foi sequer tema de debate no conjunto do governo e muito menos no Congresso Nacional". Outras questões teriam monopolizado a atenção dos parlamentares, notadamente a preocupação do governo com a agenda macro-econômica que impunha cortes orçamentários nas políticas debatidas no processo de consulta realizado (INTER-REDES, 2005).

Além disto, a Inter-Redes apontava a parcialidade do governo na incorporação das propostas debatidas no PPA. Segundo Moroni (2006, p. 16), questões periféricas, que ajudavam a desenhar melhor os mega-objetivos das orientações estratégicas do governo, foram mais incorporadas do que aquelas que afetavam a lógica das políticas e que constituíam a principal demanda das organizações nas audiências estaduais.

Destas análises resultou uma pauta com avaliações críticas à forma como foi encaminhado $\mathrm{o}$ processo participativo do PPA 2004-2007. Esta pauta consistia nos seguintes pontos: "Formação de um grupo de trabalho paritário entre governo e sociedade civil para acompanhar o monitoramento do PPA 2004-2007; construção, em parceria com representantes da sociedade civil, dos mecanismos e da metodologia de participação nos processos de revisão anual e no monitoramento do PPA; acesso às informações sobre a execução física e financeira do PPA, especificamente a disponibilidade on-line dos dados do Sistema Integrado de Administração Financeira (Siafi) e do Sistema de Informações Gerais e de Planejamento (Sigplan); elaboração de indicadores desagregados por gênero, raça, etnia, rural, urbano, etc., permitindo acompanhamento mais qualitativo do impacto real das políticas públicas por parte das representantes da sociedade civil" (idem).

Mediante tal avaliação, a SG-PR/SNAS elaborou novas regras para a elaboração do PPA 20082011, que consistem, segundo documento da própria secretaria, (1) na valorização dos canais de participação social já existentes, como os Conselhos, as Conferências e os Fóruns. A justificativa para tal estratégia vincula-se à crença dos membros da SG-PR de que a participação social no PPA 2008-2011 já teria começado nas conferências realizadas no período anterior (2003-2006) e que continuará por meio da atuação dos Conselhos que passarão a selecionar e priorizar as deliberações e as recomendações da sociedade realizadas nas conferências e nos fóruns; (2) na construção conjunta, pelos Ministérios e pelos Conselhos, das diretrizes ministeriais - problemas e políticas públicas - para a elaboração do PPA; (3) na transparência para a sociedade das contribuições aproveitadas no PPA 2008-2011; (4) na participação social na implementação do PPA ao longo do ciclo orçamentário (BRASIL. SECRETARIA-GERAL DA PRESIDÊNCIA. SECRETARIA NACIONAL DE ARTICULAÇÃO SOCIAL, 2007).

Ademais, foi instituído em março de 2007, por Decreto Presidencial, o grupo de trabalho composto pelos seguintes representantes do governo e da sociedade civil: do governo, estão representados a) Secretaria-Geral da Presidência da Re- 
pública; b) Ministério do Planejamento, Orçamento e Gestão; c) Ministério da Fazenda; e d) Casa Civil da Presidência da República; da sociedade civil, estão representados a) Associação Brasileira de Organizações Não-Governamentais (Abong); b) Articulação de Mulheres Brasileiras (AMB); e c) duas outras entidades a serem definidas pela Secretaria-Geral da Presidência da República (BRASIL. PRESIDÊNCIA DA REPÚBLICA, 2007).

As atribuições deste grupo de trabalho são: 1) definir a forma e o escopo da participação social no acompanhamento da elaboração e execução do PPA, da LDO e da LOA; 2) constituir Fórum Permanente de Acompanhamento da elaboração e execução do PPA, da LDO e da LOA com sugestões acerca de sua atribuição, composição, vinculação, funcionamento e eleição dos representantes da sociedade civil; 3) propor a forma e o procedimento de acesso da sociedade civil ao Sistema Integrado de Administração Financeira do Governo Federal (SIAFI) e ao Sistema de Informações Gerenciais e de Planejamento (Sigplan).

Tanto as inovações realizadas para a elaboração do PPA 2008-2011 - racionalização dos canais de participação, partilhamento entre governo e sociedade na elaboração das diretrizes políticas que comporão o PPA, transparência sobre as diretrizes incorporadas no PPA e o monitoramento da sua implementação - quanto a formação de um grupo de trabalho paritário, com atores e funções definidas, apontam, mais uma vez, para a disposição do atual governo em incluir politicamente os atores societários nas discussões e decisões referentes às políticas públicas desenvolvidas pelo mesmo. $\mathrm{O}$ aperfeiçoamento do método participativo, a partir do diálogo com os representantes da sociedade civil - Abong e ABM também corroboram esta disposição. Entretanto, para além da tentativa de ampliação e aperfeiçoamento de cada um dos itens que constituem tal método, uma questão anterior deve ser levantada, qual seja, a centralidade deste mesmo método na política de governo do Presidente Lula. Mais uma vez, vale lembrar que a sinergia positiva entre os atores estatais e societários depende muito, embora não somente, desta centralidade (EVANS, 1996; TENDLER, 1998). Esta parece ser também a opinião dos próprios atores no governo Lula. Segundo a ex-Secretária-Adjunta da SNAS, "para uma metodologia [participativa] como esta ter sucesso, ela precisa que a Casa Civil, o Planejamen- to e a Secretaria-Geral convoquem os outros ministros [e] os secretários executivos para a elaboração participativa do PPA e determine qual será o processo de participação. Mas, isso não aconteceu porque a máquina pública, os ministérios, toda a energia e todo o esforço ficou voltado para o Plano de Aceleração do Crescimento (PAC). [...] O PPA deixou, naquele momento, de ser uma pauta prioritária dentro do governo" 20 .

Para implantar o PAC, carro-chefe da política de desenvolvimento do segundo mandato presidencial, as negociações em torno da concretização da dinâmica participativa do PPA 2008-2011 foram interrompidas, suspendendo, assim, as articulações anteriormente estabelecidas. $\mathrm{O}$ que temos parece ser, novamente, limites colocados pelo próprio governo sempre que novas necessidades sistêmicas surgem: no primeiro mandato, o superávit primário; no segundo, os planos setoriais de aceleração do crescimento. Se a dinâmica participativa não assume uma posição central na lógica governamental, a sinergia almejada fica comprometida, principalmente se levarmos em consideração a pluralidade de atores que compõem o governo, como também a resistência de muitos deles em relação à forma participativa de gestão pública.

Como aponta Evans (2006), a complementariedade exigida para a realização de relações cooperativas requer uma interação constante entre representantes públicos e comunidades que só se concretiza na presença de um conjunto de instituições competentes e engajadas. Este engajamento, aliado a uma sociedade civil mobilizada, pode fornecer as bases de sustentação para uma gestão pública efetivamente particpativa e inclusiva. Em um contexto complexo como o nacional, as idas e vindas do governo no que tange à centralidade desta forma de gestão pode tornar a participação um recurso meramente ritualístico, compromentendo a possibilidade inovadora que o método participativo construído em diálogo com os representantes da sociedade civil comporta.

\section{CONSIDERAÇÕES FINAIS}

As políticas participativas do governo Lula foram analisadas neste artigo sob o enfoque da inclusão política. Entendemos por inclusão política um conjunto de ações que possibilitam aos par-

20 Entrevista realizada em 27 de junho de 2007. 
ticipantes intervirem nos processos decisórios das políticas a que se vinculam.

Acreditamos que o surgimento, a disseminação e a reforma dos canais participativos presentes no cenário político brasileiro desde a década de 1990 são fundamentais para simultaneamente fortalecer o tecido social, abrir mais possibilidades de vocalização de novos interesses e identidades e alargar os limites do sistema político. Entretanto, como bem mostra a literatura sobre deliberação pública (COHEN \& SABEL, 1997; BOHMAN, 1998; DRYZEK, 2002; FUNG \& WRIGHT, 2003), a presença desses canais não garante, por si só, que estas mesmas vozes serão incluídas nos processos decisórios destas mesmas sociedades. Para a construção de uma dinâmica cooperativa, que redunde em um processo inclusivo mais amplo, uma série de variáveis deve estar presente. Destacamos aqui, além da necessidade de uma sociedade civil ativa e atenta, a importância da presença de um conjunto de atores institucionais engajados na promoção e sustentação das inovações participativas em curso.

Ao assumir a Presidência da República, o governo Lula construiu as bases de um novo pacto com a sociedade civil organizada, por meio da criação e institucionalização de novos espaços participativos. Exemplos destas incitativas encontram-se na criação do CDES, nas novas funções assumidas pela SG-PR, no incentivo à formação de novos fóruns participativos, na elaboração e revisão de um método participativo e na criação do grupo de trabalho organizado entre representantes da sociedade civil e do governo, de forma paritária, para discutir e aperfeiçoar este mesmo método.

Tais iniciativas constituem exemplos inequívocos da disposição deste governo de ampliar suas bases de negociação e sustentação política para além dos atores politicamente instituídos como parlamentares, prefeitos e governadores, construindo, assim, formas mais criativas de governabilidade e de desenvolvimento do país. Não obstante, como também ressaltado neste artigo, em que pese os avanços obtidos no que tange à incorporação das OSCs na discussão sobre as diretrizes governamentais, é necessário que esta incorporação torne-se de fato uma política de governo majoritariamente sustentada. Do contrário, os esforços empreendidos até aqui para a construção e o aperfeiçoamento da participação nas políticas públicas do governo Lula podem tornarse marginais e seletivos, comprometendo, assim, as potencialidades inclusivas que estes mesmos esforços podem gerar.

Cláudia Feres Faria (cfaria@fafich.ufmg.br) é Doutora em Sociologia e Política pela Universidade Federal de Minas Gerais (UFMG) e Professora na mesma instituição.

\section{REFERÊNCIAS BIBLIOGRÁFICAS}

ABERS, R. 1998. From Clientelism to Cooperation: local government, particpatory policy, and civic organizing in Porto Alegre, Brazil. Politics \& Society, London, v. 26, n. 4, p. 511-537.

ABRÚCIO, F. L. \& COSTA, V. M. F. 1998. Reforma do Estado e o contexto federativo brasileiro. São Paulo: Fundação KonradAdenauer-Stiftung.

ALMOND, G. \& VERBA, S. 1963. The Civic Culture: Political Attitudes and Democracy in Five Nations. Princeton: Princeton University.

ARMONY, C. G. 2004. The Dubious Link: Civic Engajament and Democratization. Stanford: Stanford University.
AVRITZER, L. 2002. Sociedade civil, espaço público e poder local: uma análise do orçamento participativo em Belo Horizonte e Porto Alegre. In: DAGNINO, E. (org.) Sociedade civil e espaços públicos no Brasil. São Paulo: Paz e Terra.

(org.). 2007. Participação social no Nordeste. Belo Horizonte: UFMG.

AVRITZER, L. \& COSTA, S. 2004. Teoria Crítica, democracia e esfera pública: concepções e usos na America Latina. Dados, Rio de Janeiro, v. 47 , n. 4 , p. 26-30.

AVRITZER, A. \& PEREIRA, M. L. D. 2005. Democracia, participação e instituições híbridas. Teoria e Sociedade, Belo Horizonte, n. 
especial.

BОНМАN, J. 1996. Public Deliberation: Pluralism, Complexity and Democracy. Cambridge: MIT.

COHEN, J. \& SABEL, C. 1997. DirectlyDeliberative Poyarchy. European Law Journal, Hoboken, n. 3, p. 313-342.

COHEN, J. \& ROGERS, J. 1995. Associations and Democracy. In: WRIGHT, E. O. (ed.) The Real Utopias Project. V. I. New York: Verso.

COSTA, S. 1997. Categoria analítica ou passepartout político normativo: notas bibliográficas sobre o conceito de sociedade civil. $B I B$, Rio de Janeiro, n. 43.

DAGNINO, E. 2004. Construção democrática, neoliberalismo e participação: os dilemas da confluência perversa. Política e Sociedade, Florianópolis, v. 1, n. 5, p. 139-164. Disponível em: http:/www.journal.ufsc.br/index.php/ politica/article/viewFile/1983/1732. Acesso em: 10.mai.2010.

DAHL, R. 2000. On Democracy. New Haven: Yale University.

DRYZEK, J. S. 2002. Deliberative Democracy and Beyond. Oxford: Oxford University.

EVANS, P. 1996. Government Action, Social Capital and Development: Reviewing the Evidence on Synergy. World Development, Amsterdam v. 24, n. 6, p. 1119-1132.

2003. Além da monocultura institucional: instituições, capacidades e o desenvolvimento deliberativo. Sociologias, Porto Alegre, n. 9, p. 20-63.

FARIA, C. F. 1996. Democratizando a relação entre o poder público municipal e a sociedade civil: o orçamento participativo em Belo Horizonte. Belo Horizonte. Dissertação (Mestrado em Ciência Política). Universidade Federal de Minas Gerais.

2000. Democracia deliberativa: Habermas, Cohen e Bohman. Lua Nova, São Paulo, n. 50, p. 47-68.

2007. Sobre os determinantes das políticas participativas: a estrutura normativa e o desenho institucional dos Conselhos Municipais da Saúde e de Direitos da Criança e do Adolescente. In: AVRITZER, L. (org.) A participação so- cial no Nordeste. Belo Horizonte: UFMG

FUNG, A. 2003. Associations and Democracy. Between Theories, Hopes, and Realities. Annual Review of Sociology, Palo Alto, v. 29, p. 515-539.

FUNG, A. \& WRIGHT, E. O. 2003. Deepening Democracy. Institucional Innovations in Empowered Participatory Governance. London: Verso.

GOHN, M. G. 1995. Movimentos, ONGs e lutas sociais no Brasil dos anos 90. In: XIX Encontro Anual da Associação Nacional de Pós-Graduação e Pesquisa em Ciências Sociais (Anpocs). Caxambu.

2005. O protagonismo da sociedade civil. Movimentos sociais, ONGs e redes solidárias. São Paulo: Cortez.

HABERMAS, J. 1984. Mudança estrutural da esfera pública. Rio de Janeiro: Tempo Brasileiro.

1996. Between Facts and Norms. London: Polity.

KOSLINSKI, M. C. \& REIS, E. 2009. Transnational and Domestic Relations of NGOs in Brazil. World Development, Amsterdam, v. 37, n. 3, p. 714-725.

LANDIM, L. 1996. Nongovernmental Organizations in Latin America. In: AI CAMP, R. (ed.). Democracy in Latin America. Patterns and Cycles. Oxford: Scholarly Resources.

MANIN, B. 1997. The Principles of Representative Government. Cambridge: Cambridge University.

MORONI, J. A. 2006. O direito à participação no governo Lula. Digit.

NAVARRO, Z. 1998. Affirmative Democracy and Redistributive Development: the Case of Participatory Budgeting in Porto Alegre, Brazil (1989-1997). Porto Alegre: s/ n.

. 2003. Orçamento Participativo de Porto Alegre (1989-2002): um conciso comentário crítico. In: AVRITZER, L. \& NAVARRO, Z. (orgs.). A inovação institucional no Brasil: o orçamento participativo. São Paulo: Cortez.

NOGUEIRA, M. A. 2004. Um Estado para a sociedade civil: temas éticos e políticos para a gestão democrática. São Paulo: Cortez. 
PAOLI, M. C. 2002. Empresas e responsabilidade social: os enredamentos da cidadania no Brasil. In: SANTOS, B. S. (org.) Democratizar a democracia: os caminhos da democracia participativa. Rio de Janeiro: Civilização Brasileira.

PEREIRA, L. C. B. 1995. Modernização incompleta e pactos políticos no Brasil. In: SOLA, L. \& PAULANI, L. (orgs.) Lições da década de 80. São Paulo: USP.

PINTO, C. R. J. 2004. A sociedade civil "institucionalizada". Política e Sociedade, Florianópolis, v. 1, n. 5, p. 101-117. Disponível em: http://www.periodicos.ufsc.br/ index.php/politica/article/viewFile/1981/1730. Acesso em: 10.mai.2010.

2006. As ONGs e a política no Brasil: presença de novos atores. Dados, Rio de Janeiro, v. 49, n. 3, p. 651-670. Disponível em: http:// www.scielo.br/scielo.php? script $=$ sci arttext\&pid=S0011-52582006000300008. Acesso em: 10.mai.

PUTNAM, R. 1996. Comunidade e democracia: a experiência da Itália moderna. Rio de Janeiro: Fundação Getúlio Vargas.

SANTOS, W. G. 2006. Horizonte do desejo: instabilidade, fracasso coletivo e inércia social.
Rio de Janeiro: Fundação Getúlio Vargas.

SOUZA SANTOS, B. 1998. Participatory Budgeting in Porto Alegre: Toward a Redistributive Democracy. Politics \& Society, London, v. 26, n. 4, p. 461-510.

TABAGIBA, L 2002. Os conselhos gestores e a democratização das políticas públicas no Brasil. In: DAGNINO, E. (org.). Sociedade civil e espaços públicos no Brasil. Rio de Janeiro: Paz e Terra.

2004. A institucionalização da participação: os conselhos municipais de políticas públicas na cidade de São Paulo. In: AVRITZER, L. (org.) A participação em São Paulo. São Paulo: UNESP.

TEIXEIRA, A. C. C. 2002. A atuação das organizações não-governamentais: entre o Estado e o conjunto da sociedade. In: Dagnino, E. (org.) Sociedade civil e espaços públicos no Brasil. Rio de Janeiro: Paz e Terra.

TENDLER, J. 1998. Bom governo nos trópicos. Uma visão crítica. Rio de Janeiro: Revan.

TOCQUEVILLE, A. 1997. A democracia na América. São Paulo: USP.

WARREN, M. E. 2001. Democracy and Association. Princeton: Princeton University.

\section{OUTRAS FONTES}

ASSOCIAÇÃO BRASILEIRA DE ORGANIZAÇÕES NÃO-GOVERNAMENTAIS (ABONG). 2007. Disponível em: www.abong.org.br. Acesso em: 27.jul.

BRASIL. 2003. Lei $n$. 10 683/2003. Brasília.

BRASIL. Presidência da República. 2007. Decreto s/n. de 1/03/07. Brasília.

BRASIL. Presidência da República. Conselho de Desenvolvimento Econômico e Social. 2007. Disponível em: www.presidência.gov.br/cdes. Acesso em: 20.jul.2007.

BRASIL. Secretaria-Geral da Presidência. Secretaria Nacional de Articulação Social. s/d. Relação das Conferências Realizadas no Período 2003-2006. Brasília.
2007. Elaboração do PPA- 2008-2011: Participação Social. Brasília.

INSTITUTO BRASILEIRO DE GEOGRAFIA E ESTATÍS TICA. 1999. Perfil dos Municípios Brasileiros. Disponível em: http:// www.ibge.gov.br/home/estatistica/economia/ perfilmunic/. Acesso em: 10.mai.2010.

INTER-REDES. 2005. Comunicado Inter-Redes e ABONG 2004. Disponível em: www.interredes.org.br. Acesso em: 10.mai.2005.

2007. PPA e a Construção da Participação. Disponível em: www.inter-redes.org.br . Acesso em: 10.mai.2007. 
STATE AND CIVIL SOCIETY ORGANIZATIONS IN BRAZIL TODAY: CONSTRUCTING A POSITIVE SYNERGY?

\section{Cláudia Feres Faria}

This article seeks to analyze the relational pattern that the Lula government has maintained with movements and organizations of civil society (OSCs) in the period spanning 2003 to 2006. Its goal is to inquire as to whether and what kind of opportunities were created for the establishment of a "positive synergy" between State and civil society during this period. We start from the hypothesis that the creation of new participatory spaces, although an important condition to guarantee a truly inclusive dynamic, is in and of itself insufficient. Our analysis shows that notwithstanding the fact that the Lula government created a new pact with organized civil society through the creation, widening and institutionalization of new participatory spaces, this practice did not become a government policy that rallied majority support. Thus, the efforts that have been carried out for constructing and perfecting the participation of civil society organizations in Lula administration public policies have become marginal and selective, and thus undermine the inclusive potential that they themselves could be generating.

KEYWORDS: State; civil society organizations; participation; Lula administration. 
L'ETAT ET LES ORGANISATIONS DE LA SOCIÉTÉ CIVILE AU BRÉSIL CONTEMPORAIN : EN TRAIN DE CONSTRUIRE UNE SYNERGIE POSITIVE?

\section{Cláudia Feres Faria}

L'article cherche à analyser la structure de relation entretenue par le gouvernement Lula avec les mouvements et les organisations de la société civile (OSCs), entre 2003 et 2006. L'objectif c'est d'enquêter si des opportunités ont été créées et lesquelles, pour qu'une «synergie positive » soit 
établie entre l'Etat et la société civile pendant la même période. L'hypothèse d'où nous partons, c'est celle où la création de nouveaux espaces participatifs, malgré étant une condition importante pour assurer une dynamique inclusive effective, elle n'est pas suffisante. L'analyse faite montre que même que le gouvernement Lula ait construit les bases d'un nouveau pacte avec la société civile organisée par la création, ampliation et institutionnalisation de nouveaux espaces participatifs, telle pratique n'est pas devenue une politique de gouvernement majoritairement soutenue. De cette façon, les efforts entrepris jusqu'à ici pour la construction et l'amélioration de la participation des organisations de la société civile dans les politiques publiques du gouvernement Lula, deviennent marginaux et sélectifs, compromettant ainsi, les potentialités inclusives que ces mêmes efforts pourraient générer.

MOTS-CLES : Etat ; organisations de la société civile ; participation ; gouvernement Lula. 